\title{
DEVELOPMENT OF PISED MEDIA BASED ON REALISTIC MATHEMATICS EDUCATION IN ELEMENTARY SCHOOL
}

\author{
${ }^{1}$ Endro Siswantoro, ${ }^{2} \mathrm{Abi}$ Suwito \\ ${ }^{1}$ Sananwetan 2 Public Elementary School Blitar, ${ }^{2}$ University of Jember \\ e-mail: 1 endrosiswantorosdn2@gmail.com, 2abi.fkip@unej.ac.id
}

Accepted: 8 June 2021 I Revised: 3 November 2021 I Approved: 20 November 2021 (c) 2021 Madrasah Ibtidaiyah Teacher Education Faculty of Islamic Science, Universitas Islam Malang

\begin{abstract}
Abstrak
Materi pecahan merupakan salah satu materi matematika yang dipelajari oleh siswa kelas VI sekolah dasar. Materi tersebut secara umum masih dirasa sulit oleh sebagian besar siswa. Hal ini diketahui bahwa, masih ada siswa yang melakukan kesalahan pada operasi penjumlahan dan pengurangan khususnya pada materi pecahan. Selain itu, siswa juga mengalami kesalahan konsep pada saat mengerjakan dikarenakan pembelajaran siswa berfokus pada tulisan angka ataupun bilangan yang terdapat pada papan tulis dan buku. Berkenaan dengan itu diperlukan pengembangan pada media pembelajaran yang berbasis realistic mathematics education. Hal ini dikeranakan untuk menghadirkan pembelajaran secara real dan tidak terbatas pada media yang masih bersifat konvensional. Metode penelitian pengembangan ini terdiri dari 9 tahap yaitu (1) identifikasi potensi masalah, (2) pengumpulan data, (3) desain produk, (4) validasi desain media, (5) revisi desain media (tahap I), (6) uji coba kelompok kecil produk media, (7) revisi produk (tahap II), (8) uji coba kelompok besar, dan (9) revisi produk (tahap III). Berdasarkan hasil pengembangan didapatkan bahwa media PISED dapat dibuat dan dimanfaatkan secara mudah dengan mengandalkan sedotan. Media pembelajaran tersebut telah diuji dan mendapatkan kategori valid serta layak untuk digunakan.
\end{abstract}

Kata Kunci: Media PISED, Realistic Mathematics Education, Materi Pecahan

\begin{abstract}
Fractions subject is one of the mathematics subjects studied by grade VI elementary school students. The subject is generally still considered difficult by most students. It is known that there are still students who make mistakes in addition and subtraction operations, especially in the fractional subjects. In addition, students also experience conceptual errors when working. In this regard, learning media based on realistic mathematics education is needed. This development research method consists of 9 stages are (1) identification of potential problems, (2) data collection, (3) product design, (4) media design validation, (5) media design revision (stage I), (6) small group trial of media products, (7) product revision (stage II), (8) large group trial, and (9) product revision (stage III). Based on the development results, it was found that PISED media can be made and used easily by relying on straws. The learning media has been tested and obtained a valid and feasible category for use.
\end{abstract}

Keyword: PISED Media, Realistic Mathematics Education, Fractions subject 


\section{INTRODUCTION}

Essential components that influence student success in learning are the role of teachers, teaching materials, learning strategies, media, and learning resources (Zein, 2016; Andiyanto, 2017). These components are critical in learning, even though mathematics learning in some schools today is only in the form of brief explanations, examples of questions, and completion of assignments. Students get too abstract lessons, use many formulas that are not following students' daily lives, and certainly do not provide learning experiences (Setiani, et al., 2015; Nurhikmayati, 2017). Mathematics learning should be realistic (accurate) following students' daily lives, fun, and provide a learning experience and ultimately impact students' creativity to solve the problems they face. Active, creative, effective, and fun learning (standard) and Contextual Teaching Learning (CTL) need to be realized by teachers so that students can achieve the expected standard of mathematical competence (Yusnita \& Munzir, 2017). The standard or CTL can be realized if teachers have creativity and innovate to implement appropriate learning strategies and approaches.

One of the abstract mathematics materials in grade VI elementary school is fraction material (Ananda, 2018; Unaenah \& Sumantri, 2019; Setiawan, et al., 2020). Based on the results of observations carried out at SDN Sananwetan Blitar City, it is known that students do not understand the material for addition and subtraction of fractions because the learning that takes place is still conventional. Conventional learning is more teacher-centered than student-centered (Abdullah, 2017; Adim et al., 2020). The teacher dominates the teaching and learning activities while the students act as listeners or note-takers. Teachers often view mathematics as a product and not a process. Therefore, in learning activities, teachers tend to transfer their mathematical knowledge into students' minds without constructing their mathematical knowledge. This is reinforced by Marbun (2019) that mathematics learning in elementary schools (SD) currently tends to use LKS sold from publishers and textbooks.

Mathematics Student Worksheets (LKS), which are widely used, are not designed to develop creative thinking. This situation is one of the triggers for low student activity. At the same time, Nuraini et al. (2017) found that $61 \%$ of students experienced errors in fractional addition operations and $63.3 \%$ of students in fractional subtraction operations. Student errors include procedural errors, conceptual errors, errors in misinterpreting instructions. To overcome these problems, the effort is to minimize the errors in the concept of addition and subtraction of fractions experienced by students through a realistic mathematical approach using Pised media (Pipa Straws).

According to Bruner, to minimize conceptual errors or improve understanding of the concept of fractions, you can follow the stages of learning mathematics. The stages in question are enactive, iconic, and symbolic (Sagala et al., 2018). The enactive stage is the learning stage by manipulating objects or objects concretely; the iconic stage is the stage of learning by using pictures; and the symbolic stage, namely learning through manipulating symbols or symbols. Understanding of mathematical concepts, especially fractions, can be done by students through activities related to natural 
objects (concrete experiences) so that their minds can accept them. This is supported by the theory of cognitive development of children proposed by Jean Piaget. While Piaget divided the cognitive development of children into four stages, namely: (1) Sensorimotor stage (0-2 years), the child's experience is obtained through physical and sensory-motor actions; (2) the pre-operational stage (2-7 years), the stage of preparation for organizing concrete operations; (3) The concrete operational stage (711 years), children understand logical operations with the help of concrete objects; and (4) the formal operational stage (11 years and over), children can reason using abstract things (Ibda, 2015).

Thus, to help students learn mathematics smoothly, it is necessary to support learning media to increase students' ability to add and subtract fractions. The learning media developed must provide students with a meaningful, activating, and enjoyable experience and lead to learning outcomes. This is supported by Agustina (2020), who states that students at lower levels will more easily understand and understand the concept by presenting abstract mathematical concepts in concrete form. The development and use of media are focused on learning the material for addition and subtraction of fractions for students through a realistic mathematical approach. The learning media used are close to the students' world and are simple in their environments, such as a straw pipette or a small pipe with minimal diameter. This straw pipe or small pipe is a learning media made by students as a genuine work that must get appreciation from the teacher and his colleagues.

\section{METHOD}

The type of research used in this research is development research. Development research is a type of research method used to develop and produce certain development products and test the developed products' effectiveness (Sugiyono, 2015). This development research model consists of a conceptual model, a procedural model, and a systematic model. The conceptual model is an analytical model that explains the interrelationships of the product components to be developed and the product components themselves. In contrast, the procedural model is descriptive or has steps that must be followed to produce a particular development product. The steps in the procedural model must be followed from the initial step to the final step without changing each step of the procedural model (Setyosari, 2013).

Researchers develop media based on a realistic approach using the Sugiyono (2015) model with the rationalization that (a) changing student-centered learning, so that students can learn independently, (b) developing teacher abilities in planning or developing learning tools according to student characteristics, and (c) the researcher uses the type of development research, because in this study what was developed was PISED teaching media that teachers had never used. Therefore, researchers developed PISED teaching media to be a reference for teachers in developing teaching media. The steps in this development research are as follows. 


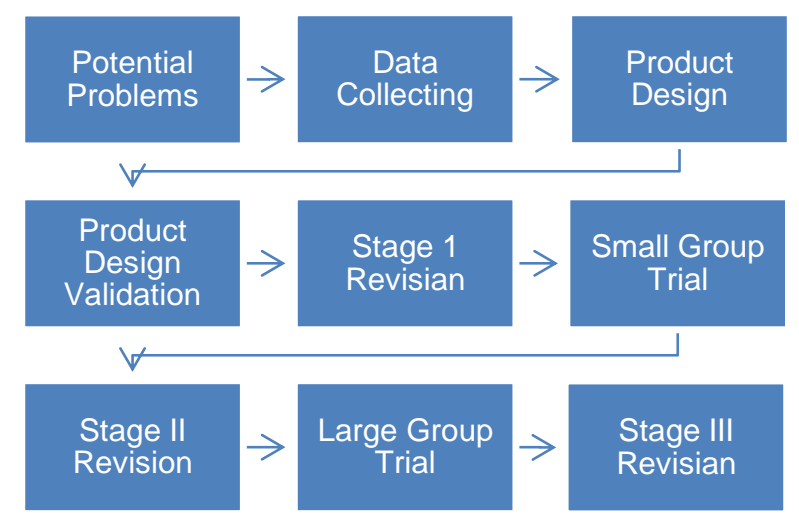

Figure 1. Stages of Research Development

\section{RESULTS AND DISCUSSION}

In general, this development product has differences from other media, namely the media developed based on realistic mathematics education on fractional material. Media Pised was developed for grade VI SD Sananwetan 2 Blitar City. The product developed is expected to be following the learning objectives. Learning media for addition and subtraction of fractions is divided into (1) a seat and (2) a straw fraction. Make a pipe holder by cutting banana stems or toy wax. Once formed, plug the pieces of bamboo (sticks) that have been sharpened. Picture the pipe holder as a holder, as shown in Figure 2 below.

Figure 2. Seat Position

Making display pipe shards (broken straws) by cutting inch pipes or straws into ten pieces, each measuring $30 \mathrm{~cm}$ or other sizes. The second to tenth pipe (straw pipette) is cut into pieces except for the first pipe. The second pipe (straw pipette) is cut into two equal parts; the third pipe (straw pipette) is cut into three equal parts until the tenth pipe (straw pipette) is cut into ten equal parts. The picture of the display pipe fragment (fractured straw) is as shown in Figure 3 below.

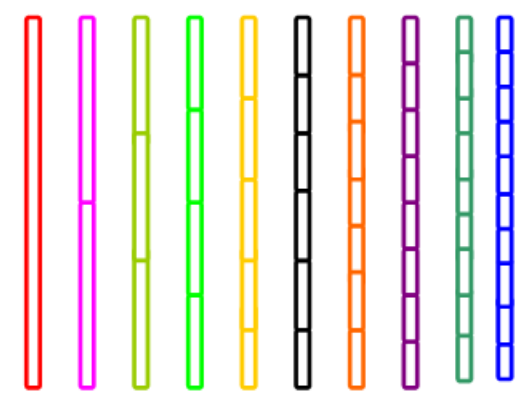

Figure 3. Broken Pipe Display (Pipett Straw) 
Based on Figure 3, it can be seen that if the fraction of the display pipe (straw pipette) is placed on the pipe holder, then it becomes a learning medium for adding and subtracting fractions.

\section{Introduction of Simple Fractions Through PISED Media}

At the stage of introducing simple fractions, students can use the learning media that have been created. The whole straw pipe or pipette at the left end is called a unit pipe or pipette unit, while the pipe on the right is called a broken pipe because it is cut into equal lengths. If the pipe (straw pipette) is cut into two equal lengths, it results in a fraction of $\frac{1}{2}$, and if the two pipes (straw pipette) are recombined, it results in a whole pipe (straw pipette) with a value of 1 . Suppose the straw pipette is cut into three equal lengths. In that case, it means produces a $\frac{1}{3}$ fraction, and the three pipes (straw pipettes) are recombined, resulting in a whole pipe (straw pipette) with a value of 1 and so on until the pipe (straw pipette) cut by ten produces a fraction of $\frac{1}{10}$.

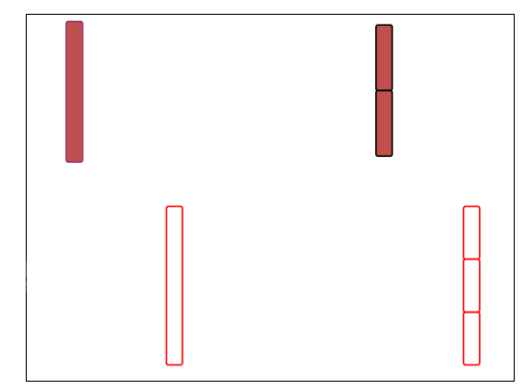

Figure 4. Introduction to Simple Fractions

\section{Counting and Writing Fractions Through PISED Media}

To count and write fractions, students pay attention to the learning media and then count them one by one. After counting one by one, students take more than one fraction pipe (fractional straw). For example, a pipe (straw) with a fraction of $\frac{1}{8}$, taking 1 is worth $\frac{1}{8}$, taking two is worth $\frac{2}{8}$, taking three is worth $\frac{3}{8}$, and so on taking eight is worth $\frac{8}{8}$.

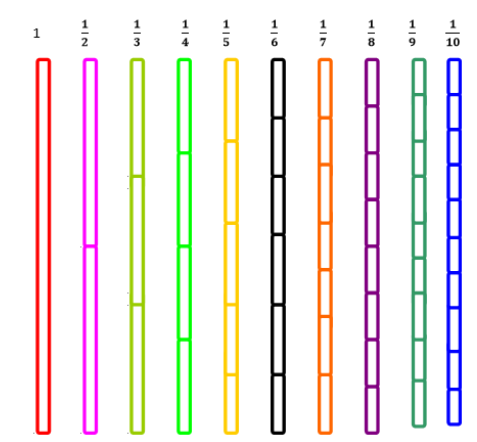

Figure 5. Fractional Pipe (Scratch Straw) 


\section{Comparing Fractions Through PISED Media}

Furthermore, in comparing two fractions, students are asked to pay attention to the learning media that shows fractions $\frac{1}{2}, \frac{1}{3}$, and $\frac{1}{4}$. If you want to compare the three, students can take 1 part each and then bring it closer to the result that the fraction $\frac{1}{2}$ is more significant than $\frac{1}{3}$, the fraction $\frac{1}{3}$ is more excellent than $\frac{1}{4}$. Based on Figure 6 below, it can be seen that writing fractions can be written as $\frac{1}{4}>\frac{1}{3}>\frac{1}{4}$ or $\frac{1}{4}<$ $\frac{1}{3}<\frac{1}{2}$

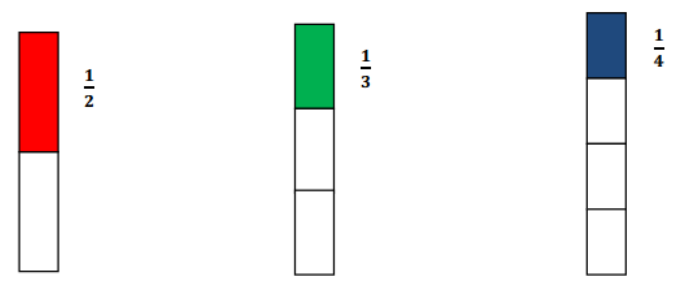

Figure 6. Comparison of Fractions

\section{Operation of Addition of Fractions through PISED Media}

In the operation of adding fractions through PISED media, an example can be taken on the addition of fractions $\frac{1}{3}+\frac{3}{6}$. Based on the operation, it can be seen that the values of $\frac{1}{3}$ and $\frac{3}{6}$ are combined. The results obtained are matched or aligned with other fractional pipes (fractional straws) so that $\frac{5}{6}$ is obtained. The visual form of PISED media can be seen in Figure 7 below.

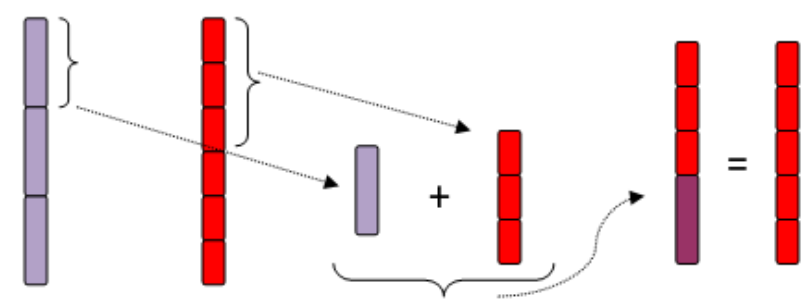

Figure 7. Operations for Adding Fractions

\section{Fraction Reduction Operations Through PISED Media}

An example is a subtraction of fractions at $\frac{3}{4}-1 / 4$. Based on Figure 8 , it can be seen that the value of $\frac{3}{4}$ is taken and then subtracted by the value of $\frac{1}{4}$. After being matched/aligned, the result is $\frac{2}{4}$, which means $\frac{3}{4}-\frac{1}{4}=\frac{2}{4}$. The following is a student's perception of the PISED media that has been developed through a questionnaire. This perception is divided into two, namely, the effectiveness of media use and efficiency 
Endro Siswantoro, Abi Suwito

of media use. Following are the results of the analysis on the first instrument item.

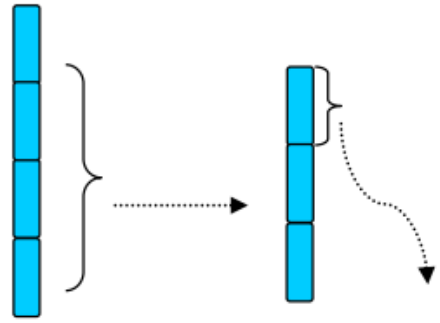

Figure 8. Fraction Subtraction Operation

Based on Figure 8, it can be seen that the value of $\frac{3}{4}$ is taken and then subtracted by the value of $\frac{1}{4}$. After being matched/aligned, the result is $\frac{2}{4}$, which means $\frac{3}{4}-\frac{1}{4}=\frac{2}{4}$. The following is a student's perception of the PISED media that has been developed through a questionnaire. This perception is divided into two, namely, the effectiveness of media use and efficiency of media use. The following are the results of the analysis on the first instrument item.

\begin{tabular}{|c|c|c|c|c|c|c|c|c|c|c|c|c|c|c|c|}
\hline \multirow[t]{2}{*}{ Respondent } & \multicolumn{15}{|c|}{ Instrument Item } \\
\hline & 1 & 2 & 3 & 4 & 5 & 6 & 7 & 8 & 9 & 10 & 11 & 12 & 13 & 14 & 15 \\
\hline 1 & 3 & 4 & 2 & 4 & 3 & 3 & 4 & 4 & 4 & 3 & 2 & 4 & 4 & 3 & 3 \\
\hline 2 & 3 & 3 & 2 & 3 & 4 & 3 & 4 & 3 & 3 & 3 & 4 & 2 & 3 & 4 & 3 \\
\hline 3 & 3 & 3 & 4 & 2 & 4 & 3 & 4 & 2 & 4 & 4 & 2 & 4 & 2 & 3 & 4 \\
\hline 4 & 3 & 3 & 4 & 4 & 4 & 3 & 3 & 3 & 4 & 2 & 2 & 3 & 4 & 3 & 4 \\
\hline 5 & 4 & 3 & 3 & 3 & 4 & 3 & 4 & 3 & 2 & 4 & 4 & 3 & 3 & 4 & 2 \\
\hline 6 & 3 & 4 & 4 & 3 & 3 & 3 & 4 & 4 & 3 & 2 & 4 & 2 & 2 & 3 & 3 \\
\hline 7 & 3 & 3 & 4 & 4 & 4 & 4 & 3 & 3 & 4 & 2 & 4 & 3 & 4 & 3 & 3 \\
\hline 8 & 3 & 4 & 4 & 4 & 3 & 4 & 4 & 3 & 4 & 4 & 4 & 3 & 4 & 4 & 4 \\
\hline 9 & 3 & 4 & 4 & 3 & 3 & 4 & 2 & 3 & 2 & 4 & 4 & 3 & 4 & 3 & 2 \\
\hline 10 & 3 & 3 & 2 & 4 & 4 & 4 & 3 & 2 & 4 & 3 & 3 & 3 & 4 & 2 & 2 \\
\hline 11 & 4 & 4 & 3 & 3 & 3 & 2 & 3 & 4 & 4 & 4 & 2 & 2 & 3 & 3 & 3 \\
\hline 12 & 4 & 4 & 2 & 3 & 4 & 4 & 3 & 3 & 3 & 4 & 3 & 4 & 4 & 3 & 4 \\
\hline 13 & 3 & 4 & 4 & 3 & 3 & 4 & 4 & 3 & 4 & 4 & 4 & 2 & 2 & 4 & 3 \\
\hline 14 & 3 & 4 & 4 & 3 & 3 & 4 & 3 & 4 & 2 & 4 & 3 & 3 & 4 & 3 & 4 \\
\hline 15 & 3 & 4 & 3 & 4 & 4 & 2 & 3 & 3 & 3 & 4 & 3 & 4 & 4 & 4 & 2 \\
\hline 16 & 4 & 3 & 4 & 3 & 4 & 2 & 4 & 3 & 4 & 3 & 3 & 4 & 2 & 4 & 2 \\
\hline 17 & 3 & 2 & 4 & 4 & 2 & 2 & 3 & 3 & 3 & 4 & 4 & 2 & 4 & 3 & 4 \\
\hline 18 & 3 & 4 & 4 & 4 & 3 & 3 & 3 & 3 & 3 & 3 & 4 & 4 & 3 & 3 & 3 \\
\hline 19 & 3 & 4 & 2 & 3 & 3 & 4 & 4 & 4 & 3 & 3 & 4 & 3 & 2 & 4 & 3 \\
\hline 20 & 3 & 4 & 4 & 2 & 3 & 4 & 4 & 3 & 3 & 4 & 2 & 3 & 4 & 3 & 4 \\
\hline
\end{tabular}


Endro Siswantoro, Abi Suwito

\begin{tabular}{llllllllllllllll}
\hline 21 & 3 & 4 & 4 & 3 & 3 & 4 & 2 & 3 & 4 & 3 & 3 & 4 & 4 & 3 & 3 \\
\hline 22 & 3 & 4 & 2 & 4 & 3 & 4 & 4 & 3 & 3 & 3 & 3 & 3 & 3 & 4 & 4 \\
\hline 23 & 3 & 4 & 4 & 3 & 4 & 4 & 2 & 4 & 3 & 3 & 3 & 3 & 4 & 4 & 2 \\
\hline 24 & 3 & 4 & 2 & 4 & 3 & 3 & 2 & 4 & 3 & 4 & 4 & 3 & 3 & 4 & 2 \\
\hline 25 & 4 & 3 & 4 & 3 & 4 & 4 & 2 & 3 & 4 & 3 & 4 & 2 & 4 & 3 & 4 \\
\hline 26 & 4 & 3 & 3 & 4 & 3 & 2 & 3 & 3 & 4 & 4 & 3 & 4 & 3 & 2 & 3 \\
\hline 27 & 4 & 3 & 4 & 2 & 3 & 2 & 3 & 4 & 4 & 2 & 3 & 3 & 4 & 4 & 3 \\
\hline 28 & 4 & 3 & 3 & 4 & 2 & 2 & 3 & 4 & 3 & 3 & 4 & 3 & 3 & 4 & 4 \\
\hline 29 & 4 & 3 & 2 & 4 & 3 & 4 & 2 & 3 & 4 & 3 & 4 & 2 & 4 & 3 & 3 \\
\hline 30 & 4 & 3 & 4 & 3 & 4 & 3 & 4 & 3 & 4 & 3 & 4 & 2 & 3 & 3 & 4 \\
\hline 31 & 3 & 4 & 3 & 4 & 3 & 3 & 4 & 4 & 4 & 4 & 4 & 2 & 4 & 3 & 4 \\
\hline 33 & 4 & 4 & 3 & 3 & 3 & 3 & 4 & 4 & 4 & 4 & 4 & 3 & 3 & 4 & 3 \\
\hline 34 & 3 & 4 & 4 & 4 & 3 & 3 & 3 & 3 & 3 & 4 & 3 & 4 & 4 & 3 & 4 \\
\hline
\end{tabular}

Table 1. Recapitulation of Students' Perceptions of PISED Media

Furthermore, relating to students' perceptions of the PISED media developed through a questionnaire on the instrument items in the second part are as follows.

\begin{tabular}{|c|c|c|c|c|c|c|c|c|c|c|c|c|c|}
\hline \multirow[t]{2}{*}{ Respondent } & \multicolumn{12}{|c|}{ Instrument Item } & \multirow{2}{*}{ Total } \\
\hline & 16 & 17 & 18 & 19 & 20 & 21 & 22 & 23 & 24 & 25 & 26 & 27 & \\
\hline 1 & 4 & 4 & 1 & 3 & 4 & 4 & 4 & 4 & 3 & 4 & 3 & 4 & 42 \\
\hline 2 & 4 & 4 & 4 & 4 & 3 & 3 & 3 & 4 & 3 & 4 & 3 & 3 & 42 \\
\hline 3 & 3 & 3 & 3 & 3 & 4 & 4 & 3 & 2 & 3 & 4 & 3 & 4 & 39 \\
\hline 4 & 3 & 4 & 3 & 3 & 3 & 4 & 4 & 4 & 2 & 3 & 4 & 3 & 40 \\
\hline 5 & 4 & 3 & 3 & 4 & 3 & 4 & 4 & 4 & 3 & 4 & 3 & 4 & 43 \\
\hline 6 & 4 & 4 & 4 & 3 & 3 & 3 & 4 & 3 & 4 & 3 & 3 & 4 & 42 \\
\hline 7 & 4 & 3 & 3 & 3 & 4 & 3 & 3 & 4 & 4 & 3 & 4 & 4 & 42 \\
\hline 8 & 3 & 4 & 4 & 3 & 4 & 3 & 3 & 4 & 4 & 3 & 3 & 3 & 41 \\
\hline 9 & 3 & 4 & 2 & 3 & 3 & 4 & 3 & 3 & 3 & 3 & 4 & 3 & 38 \\
\hline 10 & 3 & 3 & 4 & 4 & 3 & 3 & 4 & 3 & 4 & 4 & 4 & 4 & 43 \\
\hline 11 & 4 & 3 & 3 & 4 & 4 & 2 & 3 & 4 & 3 & 3 & 3 & 4 & 40 \\
\hline 12 & 3 & 4 & 3 & 4 & 4 & 3 & 4 & 3 & 4 & 2 & 3 & 4 & 41 \\
\hline 13 & 4 & 3 & 4 & 4 & 3 & 4 & 3 & 4 & 4 & 3 & 4 & 3 & 43 \\
\hline 14 & 4 & 2 & 3 & 3 & 4 & 3 & 4 & 4 & 3 & 4 & 3 & 4 & 41 \\
\hline 15 & 3 & 4 & 4 & 3 & 4 & 4 & 4 & 3 & 3 & 3 & 3 & 3 & 41 \\
\hline 16 & 3 & 4 & 3 & 3 & 4 & 3 & 4 & 3 & 4 & 3 & 4 & 4 & 42 \\
\hline 17 & 2 & 4 & 3 & 3 & 3 & 3 & 4 & 4 & 3 & 3 & 3 & 4 & 39 \\
\hline 18 & 3 & 3 & 4 & 4 & 4 & 3 & 4 & 4 & 3 & 4 & 3 & 4 & 43 \\
\hline 19 & 4 & 3 & 4 & 3 & 2 & 4 & 3 & 4 & 4 & 3 & 3 & 3 & 40 \\
\hline
\end{tabular}


Endro Siswantoro, Abi Suwito

\begin{tabular}{llllllllllllll}
\hline Respondent & \multicolumn{1}{c}{} & \multicolumn{1}{c}{ Instrument Item } & \multicolumn{2}{c}{ Total } \\
& $\mathbf{1 6}$ & $\mathbf{1 7}$ & $\mathbf{1 8}$ & $\mathbf{1 9}$ & $\mathbf{2 0}$ & $\mathbf{2 1}$ & $\mathbf{2 2}$ & $\mathbf{2 3}$ & $\mathbf{2 4}$ & $\mathbf{2 5}$ & $\mathbf{2 6}$ & $\mathbf{2 7}$ & \\
\hline 20 & 3 & 3 & 4 & 2 & 3 & 4 & 3 & 3 & 4 & 3 & 4 & 4 & 40 \\
\hline 21 & 4 & 4 & 2 & 3 & 2 & 3 & 4 & 3 & 3 & 4 & 4 & 4 & 40 \\
\hline 22 & 3 & 3 & 3 & 3 & 4 & 3 & 4 & 3 & 4 & 4 & 4 & 3 & 41 \\
\hline 23 & 3 & 3 & 4 & 4 & 2 & 4 & 3 & 3 & 4 & 4 & 3 & 4 & 41 \\
\hline 24 & 4 & 3 & 4 & 3 & 2 & 3 & 4 & 3 & 4 & 3 & 3 & 4 & 40 \\
\hline 25 & 3 & 4 & 3 & 4 & 4 & 3 & 3 & 3 & 3 & 4 & 3 & 4 & 41 \\
\hline 26 & 4 & 3 & 4 & 3 & 4 & 3 & 4 & 4 & 3 & 3 & 3 & 4 & 42 \\
\hline 27 & 3 & 4 & 2 & 3 & 4 & 3 & 3 & 4 & 3 & 3 & 4 & 3 & 39 \\
\hline 28 & 3 & 3 & 3 & 4 & 4 & 3 & 4 & 4 & 3 & 4 & 4 & 4 & 43 \\
\hline 29 & 4 & 4 & 2 & 3 & 3 & 4 & 4 & 3 & 4 & 4 & 4 & 4 & 43 \\
\hline 30 & 2 & 3 & 4 & 4 & 3 & 3 & 4 & 3 & 4 & 3 & 4 & 3 & 40 \\
\hline 31 & 4 & 4 & 3 & 3 & 3 & 3 & 4 & 4 & 3 & 3 & 3 & 3 & 40 \\
\hline 32 & 3 & 4 & 3 & 3 & 4 & 3 & 4 & 3 & 3 & 3 & 4 & 4 & 41 \\
\hline 33 & 3 & 4 & 3 & 4 & 3 & 3 & 4 & 4 & 4 & 4 & 2 & 4 & 42 \\
\hline 34 & 4 & 4 & 1 & 3 & 4 & 4 & 4 & 4 & 3 & 4 & 3 & 4 & 42 \\
\hline & & & & & Total & & & & & & 1397
\end{tabular}

Table 2. Recapitulation of Student Perceptions of PISED Media Part Two

Based on Table 1, it can be seen that the effectiveness of using media is in items 1 to 15 , and the efficiency of using media is in points 16 to 27 . The feasibility of using PISED media is $82.75 \%$. Meanwhile, the feasibility of using PISED media efficiency is $85.60 \%$, and the overall final result is $84.01 \%$. Based on the calculations that have been done, it can be seen that the level of validity and the PISED media assessment based on realistic mathematics education in the grade VI Elementary School fraction material is included in the right and appropriate level for use in the learning process. With the implementation of PISED media based on realistic mathematics education on fractional material, grade VI elementary school students can use it well and optimally. This is because PISED media can be used as a game as well as meaningful, realistic learning. Nugraheni (2017) \& Barubara (2018) support this statement because the characteristics of elementary school students tend to learn to use game media. Putra \& Nurfauziah (2015) and Setiawan (2020) also added that applying realistic mathematics education can improve students' ability to solve problems independently.

\section{CONCLUSION}

PISED media based on realistic mathematics education in grade VI Elementary School fractions is a learning media that can be used quickly and meaningfully. In 
general, this learning media can be used in learning the addition and subtraction of fractions. As for making PISED media, it is enough to use a straw divided into a holder and straw shards that can be adjusted or adapted to the needs of learning fractions. Based on the test results of the effectiveness of the use of media and the efficiency of the use of media, it was found that the PISED media based on realistic mathematics education on fractional material was included in the valid and feasible category to use.

\section{REFERENCE}

Abdullah, A. 2017. Pendekatan dan model pembelajaran yang mengaktifkan siswa. EDURELIGIA: Jurnal Pendidikan Agama Islam, 1(1), 45-62.

Adim, M., Herawati, E. S. B., \& Nuraya, N. 2020. Pengaruh model pembelajaran contextual teaching and learning (CTL) menggunakan media kartu terhadap minat belajar IPA kelas IV SD. Jurnal Pendidikan Fisika dan Sains (JPFS), 3(1), 612.

Agustina, S. V. 2020. Social Interaction \& Natural Environment Based Learning. Zirah, 1(2), 137-145.

Ananda, R. 2018. Penerapan pendekatan realistics mathematics education (RME) untuk meningkatkan hasil belajar matematika siswa sekolah dasar. Jurnal Cendekia: Jurnal Pendidikan Matematika, 2(1), 125-133.

Andiyanto, T. 2017. Peran Guru Dalam Implementasi Kurikulum 2013: Studi Pada Tk Mentari Kec. Abung Selatan Kab. Lampung Utara. Elementary: Jurnal Ilmiah Pendidikan Dasar, 3(1), 73-78.

Batubara, H. H. 2018. Pengembangan media pembelajaran matematika berbasis android untuk siswa SD/MI. Muallimuna: Jurnal Madrasah Ibtidaiyah, 3(1), 1227.

Ibda, F. 2015. Perkembangan kognitif: teori jean piaget. Intelektualita, 3(1).

Marbun, L. P. S. 2019. Pengembangan Lembar Kerja Siswa Berbasis Open Ended Problem Pada Materi Pecahan Untuk Siswa Sekolah Dasar. Jurnal Education And Development, 7(3), 207-207.

Nugraheni, N. 2017. Implementasi permainan pada pembelajaran Matematika di sekolah dasar. Journal of Medives: Journal of Mathematics Education IKIP Veteran Semarang, 1(2), 142-149.

Nuraini, N. L. S., Suhartono, S., \& Yuniawatika, Y. 2017. Kesalahan Siswa pada Operasi Penjumlahan dan Pengurangan Pecahan di Kelas VI Sekolah Dasar. Sekolah Dasar: Kajian Teori dan Praktik Pendidikan, 25(2), 168-175.

Nurhikmayati, I. 2017. Kesulitan berpikir abstrak matematika siswa dalam pembelajaran problem posing berkelompok. Kalamatika: Jurnal Pendidikan Matematika, 2(2), 159-176.

Putra, H. D., \& Nurfauziah, P. 2015. Analisis Penerapan Pembelajaran Berbasis 
Pendidikan Matematika Realistik Indonesia Di SD/MI Kota Bandung. Jurnal Ilmiah P2M STKIP Siliwangi, 2(1), 7-18.

Sagala, V., \& Hatip, A. 2018. Peningkatan lapisan pemahaman konsep luas bangun datar mahasiswa melalui model pembelajaran PRAKTAK. Jurnal Didaktik Matematika, 5(2), 30-39.

Setiani, N. L., DANTES, D. N., CANDIASA, D. I. M., \& Komp, M. I. 2015. Pengaruh Pendekatan Pembelajaran Matematik Realistik Terhadap Semangat Belajar Dan Hasil Belajar Matematika Siswa Kelas Vi Pada Sdlb. BN Sidakarya. Jurnal Penelitian dan Evaluasi Pendidikan Indonesia, 5(1).

Setiawan, Y. U., Yandari, I. A. V., \& Pamungkas, A. S. 2020. Pengembangan Kartu Domino Pecahan Sebagai Media Pembelajaran Matematika Di Kelas Iv Sekolah Dasar. Primary: Jurnal Keilmuan Dan Kependidikan Dasar, 12(1), 1-12.

Setiawan, Y. 2020. Pengembangan Model Pembelajaran Matematika SD Berbasis Permainan Tradisional Indonesia dan Pendekatan Matematika Realistik. Scholaria: Jurnal Pendidikan Dan Kebudayaan, 10(1), 12-21.

Setyosari, Punaji. 2013. Metode Penelitian Pendidikan dan Pengembangan. Jakarta: Kencana.

Sugiyono. 2015. Metode Penelitian Pendidikan Pendekatan Kuantitatif, Kualitatif dan R\&D. Bandung: Alfabeta.

Unaenah, E., \& Sumantri, M. S. 2019. Analisis Pemahaman Konsep Matematis Siswa Kelas 5 Sekolah Dasar Pada Materi Pecahan. Jurnal Basicedu, 3(1), 106-111.

Yusnita, Y., \& Munzir, M. 2017. Peningkatkan Hasil Belajar Pelajaran Ips Dengan Contextual Teaching Learning Melalui Media Gambar Siswa Sekolah Dasar. Faktor: Jurnal Ilmiah Kependidikan, 4(1), 23-38.

Zein, M. 2016. Peran guru dalam pengembangan pembelajaran. Jurnal Inspiratif Pendidikan, 5(2), 274-285. 